leave no doubt that Dr. Schapera is right. Mr. René Ellenberger found that in the praisesongs (dithoko) of the Tlokwa chiefs there is not a word to show that they conquered any tribes north of the Vaal, or indeed that they ever crossed that river. 'There is no denying', he wrote, "that the BaFokeng of Sebetwane were pushed out of their country by the BaTlokwa of MmaNtatisi '; but she ' did not fight him at Dithakong nor did the pursuit go over the Vaal river. ... It is as clear as daylight that it was the Maphuting of Tshwane and the BaHlakwana of Nkarahanye who were unmercifully destroyed neat Kuruman under the name of "Mantatees" and not, as written by Theal, Cory, and others, the BaTlokwa of MmaNtatisi'. All the information he obtained in I91s from old Maphuting was unanimous that Tshwane was killed by the Makulukama (' coloured people', i.e. Griquas) in a fearful fight beyond the Vaal river. This may seem a trivial matter, but in the interest of historical accuracy it is well to draw attention to it : the importance of the battle has been recognized by historians. In the light of this information, a revision of Professor Eric Walker's standard history of South Africa at page x 82, and of Professor Macmillan's chapter in the Cambridge History of the British Empire, viii, p. 302, is necessary. It is to be hoped that René Ellenberger's collected material will be published, as well as that which his father left for another volume of his History.

One question remains unanswered. Sebetwane, chief of the BaFokeng (Makololo), told Dr. Livingstone in $18 \mathrm{I} I$ that he was ' one of that immense horde of savages driven back by the Griquas ', or, as Livingstone reported again, 'one of the Mantatee horde'. The story told by Ellenberger pere of a great fight at Dithakong between Sebetwane's people and the BaTlokwa, prior to the fight with the Griquas, is now denied. Since we can no longer accept the presenee of BaTlokwa at Dithakong, we want to know in what relation Sebetwane stood to the MaPhuting and the BaHlakwana. Did he arrive there independently of them, or in their company as part of the invading horde?

Communicated by Edwin W. Smith

\title{
Gold Coast Plan for Mass Literacy and Mass Education
}

The Department of Social Welfare, Gold Coast Government, has issued a paper (undated) setting forth a plan for mass literacy, mass education, and community development which, according to a Foreword signed by the Minister of Education and Social Welfare, 'has received the cordial, unanimous approval of the Legislative Assembly' and is now being put into effect by the Department of Social Welfare. The introductory section enlarges on the evils of ' ignorance due to illiteracy, isolation and prejudice', on the need for mass education and development and the basic principles of mass education campaigns, and appeals for voluntary effort and local self-help.

The plan is a comprehensive one; its basis is a concerted attack on illiteracy in all areas of the Gold Coast, combined with increased facilities for training in village betterment and the stimulation of community development as an activity of local government. Most of the teaching is to be done by voluntary effort concentrating on a three months' intensive teaching period each year in each area, the concentrated period to be repeated each year for four or five years till every village is literate. During the concentrated period ' an attempt would be made to include everyone in efficiently organised groups', presumably to continue the educational effort until the 'annual revival of enthusiasm and interest'. Rural training centres are to be established for the instruction of village leaders, and Local Development committees are to assist in implementing schemes for rural betterment initiated by village literacy groups and rural centres. A bureau for the provision of vernacular literatureprimers, readers and news-sheets, posters, booklets, \&c., is to be established. One section of the paper is devoted to staff and administration requirements, and an appendix provides estimates of capital cost, revenue (from sales of reading-material), recurrent costs, special 
expenditure (cinema-vans, \&c.). The paper is illustrated by lively pictograms showing the mass education year, phases of mass literacy work, the value of voluntary effort, and the relation between village leaders, local government staff, rural centres, and mass education teams.

\section{Fort Hare Graduation}

THE first graduation ceremony since Fort Hare Native College was affliated to Rhodes University was held at Fort Hare on 25 April, Dr. Alty, Principal and Vice-Chancellor of Rhodes University, presiding. The graduation address was delivered by Professor A. R. Radcliffe-Brown, formerly Professor of Social Anthropology at Oxford. In his address Professor Radcliffe-Brown referred to the responsibility attaching to privilege in social life, and urged those who had received the privilege of a university education to be awake to their social responsibilities and to use the education they had received for some advantage to their own people and the society in which they were placed. The most valuable thing to be learnt from any sort of education was to think and act in accordance with reason. 'However difficult it may be to cultivate reason in the world of today,' he said, 'it is worth while ... to make the attempt, and it should, I think, be the first function of a university to encourage and help all such attempts. The greatest enemy of reason is prejudice. The first requirement of the pursuit of reason is an open mind. . . If your education gives you this it gives you a precious possession.'

\section{Ecole Coloniale, Bruxelles}

L'Ecole coloniale a pour but de donner aux élèves réguliers, candidats à un emploi au service du Congo Belge et du Ruanda-Urundi, une formation spéciale en rapport avec les fonctions qu'ils auront à remplir. Elle comprend les sections suivantes:

I $^{0}$ La section Juridique, accessible aux docteurs en droit, admis comme candidats pour une place de magistrat de carrière;

$2^{\circ}$ La section générale Supérieure, accessible aux candidats à un emploi d'agent de la $3^{\circ}$ catégorie de l'Administration d'Afrique. Pour être admis à cette section les intéressés doivent être porteurs d'un diplôme universitaire obtenu après un cycle d'études complet de quatre années au moins.

$3^{\circ}$ La section générale Inférieure, accessible aux candidats à un emploi d'agent de la $4^{\circ}$ catégorie de l'Administration d'Afrique. Pour être admissible à cette section les candidats doivent notamment être porteurs d'un diplôme d'études moyennes complètes du degré supérieur.

$4^{\circ}$ La section de l'Enseignement, accessible aux candidats à un emploi dans le cadre du personnel des écoles officielles de l'administration d'Afrique. Elle intéresse les professeurs, instituteurs et institutrices, qui se destinent à l'enseignement officiel.

$5^{\circ}$ La section des Télécommunications, accessible aux candidats à un emploi dans le cadre des Télécommunications.

L'enseignement est gratuit. La durée des sessions est de 3 à 4 mois pour la section Juridique et les sections générales Supérieure et Inférieure; I mois (juillet-août) pour la section de l'Enseignement et 6 mois pour la section des Télécommunications.

\section{East African Institute of Social Research}

THE third Conference of the Institute took place at Kampala from I to 9 January 1952 . It took the form of a small meeting of Fellows which was mainly devoted to the discussion of 